\title{
Erratum to: Do personalised e-mail invitations increase the response rates of breast cancer survivors invited to participate in a web-based behaviour change intervention? A quasi-randomised 2-arm controlled trial
}

\author{
Camille E. Short ${ }^{1 *}$, Amanda L. Rebar ${ }^{2}$ and Corneel Vandelanotte ${ }^{2}$
}

\section{Erratum}

Since the publication of this article [1], we have been made aware of two errors in the manuscript.

First, it was reported that 344 participants were allocated to one of two groups. This was a typo consistent throughout the article, and should have been 334 (168 intervention, 166 control - which was reported correctly).

Secondly, the RR calculation was based on the transposed table, which produced the correct $\mathrm{p}$ value and OR, but incorrect RR (1.38 instead of 1.51). As such, it was reported that: "those sent the personalised email were 1.5 times (95\% CI $=1.18-1.93$ ) more likely to respond than those sent the generic email." This should have read: "those sent the personalised email were 1.4 times $(95 \% \mathrm{CI}=1.15-1.66)$ more likely to respond than those sent the generic email."

\section{Author details \\ ${ }^{1}$ Freemasons Foundation Centre of Men's Health, School of Medicine, University of Adelaide, Level 7, South Australian Health and Medical Research Institute, North Terrace, Adelaide 5000, Australia. ${ }^{2}$ Physical Activity Research Group, School of Human Health and Social Sciences, Central Queensland University, Building 18, Bruce Highway, Rockhampton 4702QLD, Australia.}

Published online: 20 November 2015

\section{References}

1. Short CE, Rebar AL, Vandelanotte C. Do personalised e-mail invitations increase the response rates of breast cancer survivors invited to participate in a webbased behaviour change intervention? A quasi-randomised 2-arm controlled trial. BMC Med Res Methodol. 2015;15:66. doi:10.1186/s12874-015-0063-5.

*Correspondence: Camille.short@adelaide.edu.au

${ }^{1}$ Freemasons Foundation Centre of Men's Health, School of Medicine, University of Adelaide, Level 7, South Australian Health and Medical Research Institute, North Terrace, Adelaide 5000, Australia

Full list of author information is available at the end of the article
Submit your next manuscript to BioMed Central and take full advantage of:

- Convenient online submission

- Thorough peer review

- No space constraints or color figure charges

- Immediate publication on acceptance

- Inclusion in PubMed, CAS, Scopus and Google Scholar

- Research which is freely available for redistribution

Submit your manuscript at

www.biomedcentral.com/submit

C Biomed Central 